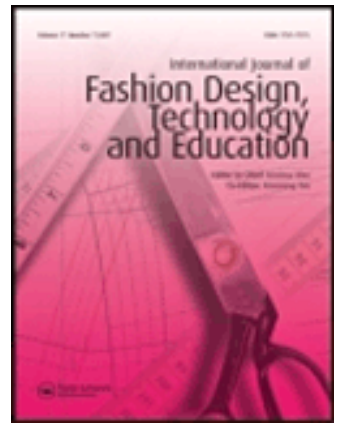

\title{
Comparative Study of Calculated and Actual Dimensions in Shaped Weft-Knitwear
}

\begin{tabular}{|r|l|}
\hline Journal: & International Journal of Fashion Design, Technology and Education \\
\hline Manuscript ID & TFDT-2018-0080.R2 \\
\hline Manuscript Type: & Technical Paper \\
\hline Keywords: & weft knitwear, fully-fashioned, fit, comfort, Armhole shaping \\
\hline \multicolumn{2}{|l}{} \\
\hline
\end{tabular}

\section{SCHOLARONE ${ }^{m}$ \\ Manuscripts}




\title{
Comparative Study of Calculated and Actual Dimensions in Shaped Weft-Knitwear
}

\begin{abstract}
This research explores and quantifies the relationship between traditional mathematical theories used for the calculation of fully-fashioned, weft-knitwear and the physical measurements of knitted garments in order to improve sizing accuracy within knitted garment production. Experiments were conducted to compare and contrast fashioning frequencies for 10-gauge knitted structures, which determined the resultant selvedge dimensions specifically within the armhole region. The trials used the geometrical principle of Pythagoras Theorem to calculate sleeve head and armhole shapes from the stitch densities. The findings identified that the greater distance between the fashionings, the less distortion occurred within the knitted structure and therefore a stronger relationship existed between the calculated seam dimensions and those measured from the physical knitted panels. The research developed new methods for calculating fit and alignment in commercial, fully-fashioned, weft-knitwear. Which provides a more sustainable fully-fashioned knitted product and has the potential to reduce returns, due to size inaccuracies.
\end{abstract}

Keywords: weft-knitwear; fully-fashioned; fit; comfort; armhole shaping

\section{Introduction}

Within traditional commercial knitwear, there are essentially two methods of knitwear production: cut and sew and fully-fashioned. Cut and sew manufacture combines different shapes after the knitted fabric has been cut from individual pattern pieces and sewn together. In contrast, fully-fashioned knitwear manufacture is where the shape of the panel is constructed during the knitting process, by decreasing or increasing the amount of stitches (or wales) within 
the panel. The resultant garment components (front, back and sleeve panel) are joined together post-knitting (Brackenbury, 1992). In the last two decades, there has been significant growth in the sale and production of fully-fashioned, weft-knitted garments (Power, 2008a; Weinswig, 2015). This is due to several factors, including the advancement in flatbed knitting technology and the ability to combine advanced structures and patterning with complex shaping. The development of variable stroke within flatbed knitting technology transformed fully-fashioned knitwear from a product largely associated with the luxury goods market to the preferred technology for high street fashion knitwear (Brackenbury, 1992; Power, 2007).

Flatbed weft-knitting technology has advanced significantly over the last three decades leading to developments that support the production of fully shaped panels, integral shaped panels and complete garment production (Black, 2002; Hunter, 2004; Anderson, 2005; Power 2007). The technology has continued to thrive beyond the millennium with further innovations, including new takedown mechanisms, yarn feeds, tension control mechanisms and more sophisticated programming software (Demerol \& Dias, 2000; Power, 2017). Design and technical teams have embraced this revolution across all sectors resulting in advances in performance and functional wear (for instance, Adidas and Nike took weft knitting into mainstream footwear; Speedo streamlined swimsuits with compression panels and Armadillo took knitwear into space). This has produced some complex and innovative designs which have lead to an unprecedented growth in knitwear within all apparel market segments (Power, 2017). Further to this, the concept of casual dress has become acceptable in the workplace, with individuals preferring the comfort and fit of knitted garments offered by improved design and manufacture (Power, 2008b; Memon, 2011; Karl, 2013). This is echoed in trends such as Athleisure, where clothing such as knitted items usually worn in athletic activities, are worn in the workplace (Goodrum, 2016; Iredale, 2017). The advancement in knitwear technology has led to a surge of creativity 
and research, as design, technical and marketing teams exploit the boundaries the machinery offers for improved shape and fit.

The focus of this paper is to devise principles to guide the development of 10-gauge fullyfashioned knitwear production to promote better size, shape and fit in the armhole area. This was achieved through the following objectives:

- To quantify the relationship between traditional mathematical theories used for the calculation of fully-fashioned, weft-knitwear and the actual physical measurements of the garment.

- To investigate the alignment of the armhole and sleeve panels in fully-fashioned, weftknitwear.

- Develop and test a new set of principles for calculating 10-gauge fully-fashioned armholes.

\section{Literature Review}

Research has shown that greater consumer satisfaction comes from selling superior fitted garments (Ashdown, 2007; Bodylabs, 2016; Dove, 2017). With the growing crisis in global garment waste, it is important to reduce the number of returned goods resulting from poor manufacturing (Allwood, 2006; Fletcher, 2007). The study of body dimensions and sizing for fashion retail markets is therefore of significant importance (Ashdown, 2007; Power, 2008b). There has been considerable, recent research into anthropometrics for the clothing industry (Gupta, 2014), with most studies based on the 1939-40, US Department of Agriculture size study. More recent studies such as, SIZE - UK, USA, Korea, China, Spain, Mexico, Canada, Thailand, France and Taiwan and the 2018 INDIAsize, use modern 3D body scanning to obtain 
measurements (Apeagyei, 2010; Kaushiki, 2018). However, data obtained from any sizing survey is only of practical use to the fashion industry when it informs the development of size charts and specifications for garment production. The literature review identified a knowledge gap in this area, which is specific to knitted garments. One of the challenges associated with knitwear is that it is possible to produce many different structures within a broad spectrum of mechanical properties (Mills, 1969; Spencer, 2001; Power, 2008). These structures range from those with superior drape that skims the body's contours to those, which are structurally rigid or exhibit elastic properties to hug and support the figure. The properties of the knitted structures influence the dimensions of garments significantly and their overall conformity to the body (Eckert et al, 2000).

Knitted garment size charts are specific to individual manufacturers as they are associated with brand differentiation (Aldrich, 2004; Power \& Otieno, 2007; Power, 2008b; Brownbridge \& Power, 2010). These are often based on empirical knowledge, gathered over many years, derived from extensive market knowledge and are ultimately aimed at meeting customer expectations in regards to size and fit. In the process of producing fully-fashioned knitwear, the formation of shape is integrated into the manufacturing of the fabric. Hence, the shaped panels (two sleeves, front panel and back panel), are joined together post-knitting and conform to the correct dimensions after the garment has been finished (in most cases this involves scouring and steam pressing to shape garment). It is also dependent on the component fibres and laundry instructions given to the consumer. If the garment panels are sized incorrectly it leads to poor fit and high returns of garments to the retailer (Le Pechoux \& Ghosh, 2002; Power and Otieno, 2007, Power, 2008b). 
In fully-fashioned, weft-knitwear, the shape specification is achieved by calculating the number of wales (stitches) and courses (rows) and uses a set of mathematical principles combined with an understanding of knitted structures and resultant fabric properties (Spencer, 2001). The knitting specification provides information relating to the timing (frequency) of the narrowings and widenings to achieve the desired shape (as defined by Spencer, 2001). The focus of this research is prominently in the armhole region of the garment. Diagram 1 illustrates the difference between a cut and sew style of sleeve and that of a shaped sleeve for both the body and sleeve panels. In fully-fashioned knitwear, the resultant panel shapes are always a compromise due to the physical movement of stitches (unlike a cut shape where a proportion of a stitch may be achieved, fully-fashioned knitwear retains all stitches through relocating them). Therefore, the actual fit of the sleeve in the 3-D form is a result of the shape of the body and sleeve panel when joined. This is a complex relationship due to the flexibility of the knitted structures, the compromise of the knitted panel shaping and the joining of the panel being completed in the unfinished state. The literature review revealed limited research that has examined the relationship between final measurements and mathematical theories used for the calculation of fully-fashioned, weft-knitwear. There is a need to establish a set of guiding principles and methods for calculating fully fashioned knitwear to promote better size and fit across the commercial sector and reduce the amount of prototyping required. This set of principles would improve the sustainability and efficiency of knitting production, resulting in less garment wastage due to fewer customer returns.

The armhole is a challenging area in terms of shape and conformity with the human form (Eckert et al, 2000). The complexity is 4-fold; firstly the translation of the irregular 3D eclipse shape required for the armhole within the body panels and sleeve head, when flattened into a 2D pattern, is intricate. Diagram 1 illustrates half a traditionally cut armhole shape (cut and 
sew), compared with that of a knitted fully-fashioned panel. Secondly, in fully-fashioned knitwear, the formed loops have been moved, which results in the deformation of the structure (this can be advantageous for comfort, but needs to be accounted for in the knitted specification). Thirdly, although the stitch densities in the body and sleeve fabric may appear identical, however they are different due to the natural deformation of the knitted stitch in panels of different sizes (this is outside the scope of this study). Finally, the armhole area joins the courses to wales within the selvedge. In the finished state (state of consolidation - which is defined as the fully relaxed state after scouring, drying in a conditioned environment, steaming and conditioning for 24 hours) this should represent the same mathematical measurements. However, in the unfinished state, the knitted dimensions are vastly different, during the manufacture process. This difference is accounted for by the skilled construction specialist (known as the linker), who would understand the requirements to achieve a smoothly joined post-finished seam through their own empirical knowledge.

[Diagram 1 near here]

It is thus reasonable to conclude that in fully-fashioned weft-knitwear, garment fit and shape are determined by the knitted structural properties. This makes a single set of knitting specification recommendations impossible (Brackenbury, 1992; Spencer, 2001; Power, 2008). It should be acknowledged, that since the calculation of knitted shaped panels is based on a set of established mathematical principles, these could be used to guide the development of accurately produced garments for a range of common armhole shapes. This research uses a plain knitted structure, to develop such a set of guiding principles on a 10-gauge flatbed weftknitting machine. 


\section{Materials and Methodology}

The research adopted a mixed methods approach that collected, integrated and analysed both quantitative and qualitative data (Corbin \& Strauss, 2008; Neuman, 2002). This merger of methods was deemed, appropriate as it established a more cohesive understanding of the research problem by combining mathematical theory with the practical activities of constructing fully-fashioned weft-knitwear. The quantitative approach included experimental research. This is a systematic and scientific approach in which variables are manipulated and the researcher measures and controls change in other variables (Saunders, et al., 2016). In this study, it included a series of experiments devised to measure the calculation of fully-fashioned knitwear and the physical measurements of the garment within the armhole area. These identified new relationships between the dimensions of knitted garment armholes and guiding principles to improve alignment, fit and comfort during wear. A qualitative approach utilising practice-based research supported the quantitative experiments. This practice utilized commercial standard knitwear technology to create garment samples. Various experiments were conducted on the samples to determine the impact on the selvedge dimensions. The samples were scrutinized, to consider how alignment, fit and comfort improved when the knitted garments were worn on the human body.

The geometry principle of Pythagoras Theorem, was selected as a theoretical formula to calculate the correct selvedge dimensions for knitted armhole measurements (Posamentier, 2010; Maor, 2007). This is a commonly understood geometrical principle which is used across the knitwear sector to calculate the correct armhole size from two standard given measurements (the chest and across the shoulders). In knitwear design, the desired armhole shape is usually elliptical however in fully-fashioned weft-knitwear the curved shape of a cut armhole, is 
impossible to achieve due to the fashioning (narrowing) of stitches. Theoretically, it is possible to narrow by $1,2,3,4$ stitches at a time. In practice narrowing beyond 2 stitches, in a single narrowing action results in a bulking of the fabric or at worst, production issues (including yarn bursts) due to excessive pressure applied during the re-location of the stitches (Spencer, 2001). In commercially produced knitwear, it is accepted practice to narrow by a maximum of 2 stitches (or 1 if there are sufficient courses to accommodate this). Pythagoras Theorem is useful to ensure there are sufficient courses available to execute the desired reduction in width. A right-angled, triangle, can be used as overlay to enable the programmer or technician to calculate the number and frequency of reductions in the knitted stitches required in order to achieve the correct armhole dimensions (Diagram 2).

[Diagram 2 near here]

A series of five experiments were conducted (Table 1) on a 10-gauge Stoll, CMS knitting machine (this is a popular gauge in mainstream knitwear - Power, 2008a). Technical parameters were controlled, by balancing the knitting cams in both knitting directions to deliver the stitch length as detailed in Table 1. The machine was calibrated at the start of each day by adjusting the tensions to deliver consistent stitch lengths, prior to loading a new knitting instruction programme. This was repeated at any yarn changes. Three different yarns were used in the experiments, all of which were commercially available. It is commonly accepted that dark colours can change the yarn properties and resultant stitch densities, even when knitted at the same stitch length, therefore the selected yarns were of a light colour as near to ecru as possible to avoid any influence of over dye. Initially $2 / 28$ high bulk acrylic was used to establish a set of common principles due to low cost and availability. Later the yarn was changed to $2 / 30$ 
Cashwool (a blend of wool and cashmere), which is a more expensive yarn associated with higher quality garment production.

The final experiment used a slightly heavier yarn which was aligned to garment production and fashion trends at the time of the research. To minimise the effect of the yarn changes, the stitch lengths were adjusted and stitch densities were re-calculated to ensure the tightness factor remained at a constant value (Table 1). The yarn was stored in a controlled condition prior to delivery in accordance with the method described in BS EN ISO 139 (20 degrees Celsius +/- 2 and $65 \%$ Relative Humidity $65 \%+/-4)$. The takedown speed, was regulated throughout the trials. Since the trials were completed on similar dimensions of fabric, this was deemed to have a negligible effect on resultant stitch density. The stitch densities detailed in Table 1, are in the state of consolidation (light scour by hand), short spin and air dried flat (in the controlled environment defined above). The resultant tightness factors for all fabrics was 1.52. Munden (1962) associated a cover factor of 1.25 with high quality knitted fabrics (by simple conversion the resulted tightness factor for high quality fabric is 1.47). In-order to assess fit and comfort during wear, the reduction in dimensions between the chest and the shoulder was $14 \mathrm{~cm}$ (experiments $1-4$, this is a common reduction used for a basic notch shape - Power, 2008b). In experiment 5, the dimensions between the chest and shoulders were adjusted to $10 \mathrm{~cm}$ to reflect a closer fitting to the body, thus accommodating a more fitted armhole and sleeve width (inset sleeve). The two-needle narrowing as detailed in Diagram 1, used a six-needle movement from the selvedge (reducing the width by two needles) to ensure a smooth selvedge area for make-up. This is an acceptable and standard commercial practice (Diagram 1). The basic relationship of Pythagoras Theorem is illustrated in Diagram 3.

[Table 1 near here] 


\section{[Diagram 3 near here]}

\section{Results}

The main objective of experiment 1 was to examine the relationship between theoretical dimensions and those yielded in the knitted fabrics state of consolidation, to determine the underpinning framework for the study. The number of wales and courses in the sample remained constant throughout the experimentation. Eighteen fashionings (narrowings) were used to reduce the width of the fabric by $7 \mathrm{~cm}$ at each selvedge (thus, representing the chest to shoulder decrease for one armhole), over intervals of 1, 2, 3 and 4 courses (fashioning frequency). The calculated 'dimension b' (Diagram 3) remained constant at $7 \mathrm{~cm}$ and the calculated 'dimension a' was increased due to the change in the fashioning frequency. The theoretical measurements are displayed in Table 2, along with the off-machine dimensions and the physical knitting dimensions in the state of consolidation. The state of consolidation is defined as a light scour (by hand) using a standard detergent solution (BS EN ISO 6330, 2012 - reference 1) in a tepid water (between 30-35 degrees Celsius). There was a short spin, and the fabric was dried flat followed with a 5 second burst of steam, then finally stored flat for 24 hours in a controlled environment as defined for the yarn conditioning (BS EN ISO139, 2005). It should be noted that this is a controlled experiment and it would be extremely rare to use a fashioning frequency of one course between fashionings in a commercial setting, due to the distortion that is created in the finished fabric or the stress put on the yarn resulting in dropped/burst stitches.

The distortion is evident from the results displayed in Table 2. The shaded column (dimension c) illustrates the knitted selvedge to be $54 \%$ of the calculated dimension. A difference of $46 \%$ 
is evident in the knitted sample for the lowest fashioning frequency (dimension c), whilst a negligible $2 \%$ is calculated at the higher frequency of four courses. Conclusively, from this basic experiment, the greater the fashioning frequencies are apart, the closer the dimensions in the knitted sample are to those calculated using Pythagoras Theorem. The issue of selvedge distortion within fully-fashioned knitwear has been highlighted in prior research (Mills, 1967), where trigonometry was used to access the differences in angles produced by different fashioning frequencies. The outcome was a series of adjustments to basic trigonometry functions to account for the distortion to the dimensions, due to the knitting construction process. Three fashioning frequencies were explored in Mills (1967) work (1, 4 and 10 courses) and similarities can be drawn from the work presented in this paper to that of Mills earlier study. Early work in knitting geometry established the reason why the measured knitted stitch was smaller than the theoretical stitch within weft-knitwear and this was due to the mechanical action of forming the stitch. The tension required to pull yarn from the package during the stitch cams increases rapidly and it becomes easier to rob yarn from the previously formed stitches rather than yarn from the package (Knapton \& Munden, 1966a; Spencer, 2001). Prior research has discussed robing of yarn for stitch formation in detail (Knapton \& Munden, 1966a, 1966b; Peat and Spicer, 1974; Pusch et al., 2000; Spencer, 2006), however since Mills 1967 study, there has been no specific research related to distortions in knitting selvedge where movement of stitches occur. This research substantiates Mills work, using an alternate method (more aligned to commercial production). It would be reasonable to conclude from this research and Mills study, that it would be almost impossible to achieve a correlation of $100 \%$ in shaped weft-knitwear and therefore a tolerance band should be acceptable. It can also be concluded that as fashioning frequencies increase beyond four courses, the physical measurements would remain constant at $98 \%$ of the theoretical measurement, and increases in 
fashioning frequencies (more courses between the narrowing actions) result in less selvedge distortion.

[Table 2 near here]

Experiment 2 expanded the preliminary investigation (experiment 1) from single panels to multiple (body and sleeve components) to assess the relationships between the theoretical and physical dimensions in garment form. It compared two commercially acceptable empirical methods (notch and raglan) designed to align the sleeve and body panels (Diagram 4). For the purpose of the research, the notch is defined as the armhole shape, which has a geometry that aligns mathematically. Diagram 4 provides a schematic figure to illustrate the relationship of the aligning components, whereby dimensions $\mathrm{X}$ on the body and sleeve panel are equal lengths in centimetres and the dimensions of $\mathrm{Y}$, are also equal in centimetres. Thus, the two triangles on the separate garment components (sleeve and body) should form hypotenuses of identical dimensions and fit together theoretically. In contrast the research defines the raglan method (not to be confused with the raglan style sleeve) as the dimensions of Y being equal in courses (knitted rows) on each of the sleeve and body components; X being equal in centimetres (on both garment components) and the dimension of $\mathrm{Z}$ (body component) being the calculated reduction required between the chest and the shoulder measurements $(7 \mathrm{~cm})$. The difference between the two methods is that the hypotenuse of the notch should align post-finishing and the hypotenuse of the raglan should align pre-finishing. In knitwear there is always a compromise since the courses and wales shrink in different proportions during finishing (usually the length reduction is greater than the width). The fully-fashioned body and sleeve components were joined pre-finishing, thus, the seams were not equal to the intended calculated dimensions in the finished state. This is clearly demonstrated in the differences between pre- 
finishing dimensions (off machine) and post-finishing (physical knitted) in Table 3. Only the selvedge of the component panels (sleeve and body) are joined, resulting in a single dimension for the hypotenuse (dimension c). This is the paradox of shaped knitwear, which has relied on the empirical knowledge of the technician to judge the best fitting calculation method.

A fully-fashioned sleeve and body panel were knitted, to examine the alignment of the two body and sleeve components. The two methods were studied over three different body fashioning frequencies (2, 3 and 4 courses). The sleeve fashioning frequencies were calculated mathematically (using Pythagoras Theorem) to ensure the components aligned as described in Diagram 4. Table 3 illustrates the theoretical dimensions compared to the physical knitted panels. The experiment set a crude line between the two empirical methods used to align the sleeve and the body panel. The shaded column (percentage difference-dimension $c$ ) demonstrates that if the number of fashionings on the sleeve is less than the body, the notch method should be used. If the body and sleeves are equal in the number of fashionings, either method could be used. However, if the sleeve consists of more fashionings than the body, the optimum method to use is that of the raglan.

[Diagram 4 near here]

[Table 3 near here]

After the initial experiment, two higher fashion frequencies were explored (6 and 8 courses), the raglan method was compared with a new method, which reduced the number of courses by $10 \%$ within the sleeve head area. The shaded columns (percentage difference) in Table 4 
illustrate the theoretical dimensions compared to the actual knitted samples in the state of consolidation (post-finishing). The results demonstrate a good alignment between the selvedge measurements in the knitted sample and those calculated (between $93 \%$ and $108 \%$ for dimension $\mathrm{C}$ using the raglan method). The $10 \%$ reduction in courses (in sleeve head) however, appears to result in a slightly better alignment between the theoretical dimensions and the physical (99-106\%). The results of experiment 3 expand the findings from experiments 1 and 2. Thus, there is evidence to suggest that increasing fashioning frequencies above 4 courses in the body results in knitting dimensions within $10 \%$ of the theoretical dimensions. This set of garments were examined further, to determine their fit to the human form. This identified that when worn, there was a noticeable distortion in the shoulder area of the garment. This was due to the steepness of the angle in which the sleeve fell, as a direct result of the increase in the sleeve head area (Diagram 5). Conclusively, the experiment was useful in terms of assessing the theoretical relationships between the calculated methods and actual knitting dimensions. However, there needed to be further modifications to the shape of the body and sleeve panels if the resultant garment was going to conform to the human form. In weft-knitwear, the sleeve width is usually reduced therefore a sloped angle is achieved in the sleeve and a sloped shoulder is used to reduce distortion in the shoulder area. This enables a closer knitting silhouette and fit to be developed, which is explored further in experiments 4 and 5 .

[Table 4 near here]

Experiment 4 modified one of the dimensions in the sleeve panel (the sleeve width, was reduced by $2 \mathrm{~cm}$ ). Whilst the research acknowledges the shoulder should be sloped to reflect the actual shape of the human form, in the experiment it was kept straight. This helped to determine a 
[Diagram 5 near here]

The final experiment explored a knitted armhole shape that fits more closely to the human form (inset sleeve - Diagram 5). The general principles learned from the prior experiments were applied as the sleeve width remained at $29 \mathrm{~cm}$ (flat). A shoulder slope of $3 \mathrm{~cm}$, was introduced on the body panel and the armhole was calculated using Pythagoras Theorem to equal $21 \mathrm{~cm}$. The $10 \%$ reduction on the raglan method was used to align the sleeve and body panels. Five separate trials were knitted and Table 5 displays the average results, which demonstrate good conformity (within the $10 \%$ tolerance) between the theoretical calculated results and those produced in the post-finished, knitted garment. When worn on the human form the sleeve conformed to the body contour and was deemed, comfortable by the wearer in the initial fit trials. In summary, the inset sleeve creates a sophisticated armhole that conforms to the body. The preferred method of calculation was the raglan with a $10 \%$ reduction in the sleeve head area. This resulted in an overall armhole shape that fitted the human form comfortably. 
[Table 5 near here]

\section{Conclusions}

The experiments identified a quantifiable relationship between the theoretical dimensions calculated using the principle of Pythagoras Theorem and the physical dimensions produced in the fully-fashioned selvedge (10 gauge weft-knitwear). The following principles were therefore, observed. A fashioning frequency of 1 course was unacceptable, fashioning frequencies of 2 and 3 courses resulted in the selvedge of the knitted samples measuring between $83-86 \%$ of the theoretical dimensions. The optimum fashioning frequency for shaping is 4 courses or above (the knitted selvedge dimensions were found to be $98 \%$ of the theoretical calculated). Further to this a comprehensive set of guiding principles were established. If the number of fashionings on the sleeve was less than the body, when aligning the body panels the notch alignment method is appropriate for use. However, if the sleeve and body fashionings are equal, either method is suitable. Finally, should the sleeve comprise of more fashionings than the body, the raglan method is appropriate for use. Further experimentation resulted in a new method for alignment, which reduced the raglan dimension by $10 \%$ in the sleeve head area, creating better conformity between the sleeve and the body panels during make-up and after finishing. This method was further explored in the use of an inset sleeve (a reduced sleeve widest, across shoulder and a slopped shoulder). The findings discovered the inset sleeve creates a sophisticated armhole that conforms to the body and the $10 \%$ reduction (raglan method) was the preferred alignment method to ensure the sleeve head fits into the armhole shape and conforms to the human body.

Ultimately, it is possible to quantify the relationship between traditional mathematical theories used for the calculation of fully-fashioned weft-knitwear and the actual physical measurements 


\section{References}

Anderson, C. (2005). Pringle: The Renaissance of a Brand. Knitting International, 112(1323), 24-26.

Aldrich, W. (2004). Metric Pattern Cutting (4 ed.). UK: Blackwell Publishing.

Allwood, J. M. (2006). Well Dressed? Technical Annex. UK: University of Cambridge. Apeagyei, P. (2010). Application of 3D Body Scanning Technology to Human Measurement for Clothing Fit. International Journal of Digital Content Technology and its Application, 4(7), $58-68$.

Ashdown, S. (2007). Sizing in Clothing. Cambridge: Woodhead.

Black, S. (2002). Knitwear in Fashion. UK: Thames and Hudson Ltd. 
Body Labs. (2016, November 13). Retail Fit Survey. Retrieved from https://www.slideshare.net/daniellaurence/body-labs-2016-retail-survey-fit

Brackenbury, T. (1992, November). Knitted Clothing Technology. UK: Blackwell Science.

Brownbridge, K., \& Power, E. J. (2010). Anthropometric Practices \& the complete Garment. Proceedings of the Textile Institute Centenary Conference. Manchester, UK. Textile Institute.

BS EN ISO 139. (2005). Standard Atmospheres for Conditioning and Testing. British Standards: BSI Group.

BS EN ISO 6330. (2012). Textiles. Domestic Washing and Drying Procedures for Textile Testing. British Standards: BSI Group.

Corbin, J., \& Strauss, A. (2008). Basics of Qualitative Research. London: Sage Publications, Inc.

Demiroz, D., \& Dias, T. (2000). A Study of the Graphical Representation of Plain Knitted Structures. Journal of the Textile Institute, 91(4), 463-480.

Dove, T. (2017, July). Women's Clothing Choices are Being Inhibited by Poor Fit. Advances in Physical Ergonomics and Human Factors. Proceedings of the AHFE 2017 International Conference on Physical Ergonomics and Human Factors. Los Angeles, USA: Springer.

Eckert, C. M., Cross, N., \& Johnson, J. H. (2000). Intelligent Support for Communication in Design Teams: Garment Shape Specifications in the Knitwear Industry. Design Studies, 21(1), 99-112.

Fletcher, K. (2008). Sustainable Fashion and Textiles. UK: Earthscan.

Goodrum, A. (2016). The Dress Issue: Introduction. Annals of Leisure Research, 19(2), 145161.

Gupta, D. (Ed.). (2014). Anthropometry, Apparel Sizing and Design. Cambridge: Woodhead Publishing Limited.

Hunter, B. (2004). Complete Garments-Evolution or Revolution? Part 2. Knitting International, 111(1319), 19-20. 
Iredale, A. (2017). The Athleisure Phenomenon: An Investigation into new Developments in the Fashion Sportswear industry (Unpublished master's thesis). University of Leeds, UK.

Karl, K. A., Hall, L. M., \& Peluchette, J. V. (2013). City Employee Perceptions of the Impact of Dress and Appearance: You Are What You Wear. Public Personnel Management, 42(3), $452-470$.

Kaushiki, D. (2018, March 5). An 'India Size Chart': What Does It Mean and Why do we Need It. Retrieved from https://imesofindia.indiatimes.com/city/delhi/an-india-size-chart-whatdoes-it-mean-and-why-do-we-need-it/articleshow/63157572.cms

Knapton, J.J.F., \& Munden, D.L. (1966a). A Study of the Mechanism of Loop Formation on Weft-Knitting Machinery: Part II: The Effect of Yarn Friction on Yam Tensions in Knitting and Loop Formation. Textile Research Journal, 36(12) 1081-1091.

Knapton, J.J.F., \& Munden, D.L. (1966b) A Study of the Mechanism of Loop Formation on Weft-Knitting Machinery: Part I: The Effect of Input Tension and Cam Setting on Loop Formation. Textile Research Journal, 36(12) 1072-1080.

Le Pechoux, B., \& Ghosh, T.K. (2002). 'Standard Sizing and Fit Testing Applied to Women's Hosiery'. Textile Progress, 32(1), 1-59.

Maor, E. (2007). The Pythagorean Theorem: A 4,000-year History. New Jersey: Princeton University Press.

Memon N. A. (2011). Knitwear Industry: Playing Vital Role in Value Addition, Pakistan Textile Journal, 34-36.

Mills, R. W. (1967). The Shaping of Plain Fabrics. Journal of the Textile Institute, 58(1), 4046.

Munden, D. L. (1962). Specification of the Construction of Knitted Fabrics. Journal of the Textile Institute, 51(1), 628-631. 
Neuman, L. (2002). Social Research Methods: Qualitative and Quantitative Methods. London: Pearson.

Peat, D., and Spicer, E.R. (1974). Yarn Movement and Tension during Loop Formation in Circular Knitting. Journal of the Textile Institute, 65(7), 388-393.

Posamentier, A. (2010). The Pythagorean Theorem: The Story of Its Power and Beauty. New York: Prometheus Books.

Power, E. J. \& Otieno R. (2007, March). Study of Anthropometrical Data in Knitted Garments. Proceedings of the Textile Institute 85th World Conference, Colombo, Sri Lanka: Textile Institute.

Power, J. (2007). Functional to Fashionable: Knitwear's Evolution Throughout the Last Century and Into the Millennium. Journal of Textile Apparel Technology and Management, $5(4), 1-16$.

Power, J. (2008). Developments in Apparel Knitting Technology. In Fairhurst, C (Ed.), Fairhurst Advances in Apparel Production. Cambridge: Woodhead.

Power, J. (2008a). Measuring up Knitting International. World Textile Publications, 114(1360), $40-41$.

Power, J. (2008b). Shaping Progress Knitting International. World Textile Publications, 114(1358), 34-35.

Power, J. (2017). Advanced Knitting Technologies for High Performance Apparel. In J. McLoughlin \& T. Sabir (Eds.), High-Performance Apparel: Materials, Developments and Applications. London: Elsevier.

Power, E. J., \& Oteino, R. (2008, November). Investigating the Relationship Between Anthropometrical Data and Fully Shaped Knitted Garments in UK Manufacturing. Proceedings of the Textile Institute 86th World Conference. Hong Kong, China. Textile Institute. 
Pusch, T., Wunsch, P., \& Offermann, P. (2000). Dynamics of Yam Tension on Knitting Machines. AUTEX Research Journal, 1(2) 54-63.

Saunders, M., Lewis, P., \& Thornhill, A. (2016). Research Methods for Business Students. UK: Pearson.

Spencer, D. (2001). Knitting Technology. Cambridge: Woodhead.

Spencer, D. (2006). Knitting Technology $3^{\text {rd }}$ Edition. Cambridge: Woodhead.

Weinswig, D. (2015). A Deep Dive into Sweaters. Fung Business Intelligence Centre, 1-22. 
Tables

\begin{tabular}{|c|c|c|c|c|c|}
\hline No & Purpose of experiment & Yarn & Stitch density & Stitch length & $\begin{array}{l}\text { Tightness } \\
\text { Factor } \\
(\mathrm{TF}) *\end{array}$ \\
\hline 1 & $\begin{array}{l}\text { Examine into the relationship } \\
\text { between theoretical } \\
\text { dimensions and those yielded } \\
\text { in the knitted fabrics state of } \\
\text { consolidation. }\end{array}$ & $\begin{array}{l}2 \times 2 / 28 \\
\text { Acrylic }\end{array}$ & $\begin{array}{l}7.22 \text { courses } / \mathrm{cm} \\
5.13 \text { wales } / \mathrm{cm}\end{array}$ & $\begin{array}{l}161 \mathrm{~cm} / 200 \\
\text { needles }\end{array}$ & 1.52 \\
\hline 2 & $\begin{array}{l}\text { Comparative study } 1 \text { of } \\
\text { calculation methods used for } \\
\text { an optimum fully fashioned } \\
\text { notch armhole. }\end{array}$ & $\begin{array}{l}2 \times 2 / 28 \\
\text { Acrylic }\end{array}$ & $\begin{array}{l}7.22 \text { courses } / \mathrm{cm} \\
5.128 \text { wales } / \mathrm{cm}\end{array}$ & $\begin{array}{l}161 \mathrm{~cm} / 200 \\
\text { needles }\end{array}$ & 1.52 \\
\hline 3 & $\begin{array}{l}\text { Comparative study } 2 \text { of } \\
\text { calculation methods used for } \\
\text { an optimum fully fashioned } \\
\text { notch armhole. }\end{array}$ & $\begin{array}{l}2 \times 2 / 30 \\
\text { Cashwool }\end{array}$ & $\begin{array}{l}7.00 \text { courses } / \mathrm{cm} \\
5.00 \text { wales } / \mathrm{cm}\end{array}$ & $\begin{array}{l}155 \mathrm{~cm} / 200 \\
\text { needles }\end{array}$ & 1.52 \\
\hline 4 & $\begin{array}{l}\text { Comparative study } 3 \text { of } \\
\text { calculation methods used for } \\
\text { an optimum fully-fashioned } \\
\text { notch armhole with reduced } \\
\text { sleeve widest. }\end{array}$ & $\begin{array}{l}2 \times 2 / 30 \\
\text { Cashwool }\end{array}$ & $\begin{array}{l}7.00 \text { courses } / \mathrm{cm} \\
5.00 \text { wales } / \mathrm{cm}\end{array}$ & $\begin{array}{l}155 \mathrm{~cm} / 200 \\
\text { needles }\end{array}$ & 1.52 \\
\hline 5 & $\begin{array}{l}\text { To apply the theories } \\
\text { established from Experiment } \\
\text { 1-4 to a garment with an inset } \\
\text { sleeve. }\end{array}$ & $\begin{array}{lr}2 \mathrm{x} & 2 / 27 \\
\text { Cashwool }\end{array}$ & $\begin{array}{l}6.51 \text { courses } / \mathrm{cm} \\
4.70 \text { wales } / \mathrm{cm}\end{array}$ & $\begin{array}{l}158 \mathrm{~cm} / 200 \\
\text { needles }\end{array}$ & 1.52 \\
\hline
\end{tabular}

Table 1 - Experiment framework for study 


\begin{tabular}{|c|c|c|c|c|c|c|c|c|c|c|c|c|}
\hline \multirow[t]{2}{*}{$\begin{array}{l}\text { Fashioning } \\
\text { frequency }\end{array}$} & \multicolumn{3}{|c|}{$\begin{array}{l}\text { Theoretical } \\
\text { dimensions } \\
(\mathrm{cm})\end{array}$} & \multicolumn{3}{|c|}{$\begin{array}{l}\text { Off machine } \\
\text { dimensions } \\
\quad(\mathrm{cm})\end{array}$} & \multicolumn{3}{|c|}{$\begin{array}{l}\text { Physical knitted } \\
\text { dimensions } \\
\text { (state of } \\
\text { consolidation) } \\
\text { (cm) }\end{array}$} & \multicolumn{3}{|c|}{$\begin{array}{c}\% \text { difference } \\
\text { theoretical and } \\
\text { physical }\end{array}$} \\
\hline & $\mathrm{a}$ & $\mathrm{b}$ & $\mathrm{c}$ & $\mathrm{a}$ & $\mathrm{b}$ & $\mathrm{c}$ & $\mathrm{a}$ & $\mathrm{b}$ & $\mathrm{c}$ & $\mathrm{a}$ & $\mathrm{b}$ & $\mathrm{c}$ \\
\hline 1 course & 2.4 & 7.0 & 7.4 & 2.0 & 4.0 & 4.4 & 1.5 & 4.5 & 4.0 & 64 & 64 & 54 \\
\hline 2 courses & 4.7 & 7.0 & 8.4 & 6.0 & 6.0 & 7.5 & 4.7 & 6.5 & 7.0 & 100 & 93 & 83 \\
\hline 3 courses & 7.1 & 7.0 & 9.9 & 6.5 & 7.3 & 7.5 & 7.0 & 6.5 & 8.5 & 99 & 93 & 86 \\
\hline 4 courses & 9.4 & 7.0 & 11.7 & 11.0 & 7.0 & 13.0 & 9.5 & 6.5 & 11.5 & 101 & 93 & 98 \\
\hline
\end{tabular}

Table 2 Comparison of fully-fashioned theoretical dimensions and Physical 


\begin{tabular}{|c|c|c|c|c|c|c|c|c|c|c|c|c|c|c|c|}
\hline \multirow[t]{2}{*}{$\begin{array}{l}\text { Calculation } \\
\text { method }\end{array}$} & \multirow[t]{2}{*}{$\begin{array}{l}\text { Garment } \\
\text { component }\end{array}$} & \multirow[t]{2}{*}{$\begin{array}{l}\text { Number of } \\
\text { fashionings }\end{array}$} & \multirow[t]{2}{*}{$\begin{array}{l}\text { Fashioning } \\
\text { frequency }\end{array}$} & \multicolumn{3}{|c|}{$\begin{array}{l}\text { Theoretical } \\
\text { dimensions } \\
(\mathrm{cm})\end{array}$} & \multicolumn{3}{|c|}{$\begin{array}{l}\text { Off machine } \\
\text { dimensions } \\
(\mathrm{cm})\end{array}$} & \multicolumn{3}{|c|}{$\begin{array}{l}\text { Physical knitted } \\
\text { dimensions } \\
(\mathrm{cm}) \text { (state of } \\
\text { consolidation) }\end{array}$} & \multicolumn{3}{|c|}{$\begin{array}{c}\% \text { difference } \\
\text { theoretical and } \\
\text { physical }\end{array}$} \\
\hline & & & & $\mathrm{a}$ & $\mathrm{b}$ & $\mathrm{c}$ & $\mathrm{a}$ & $\mathrm{b}$ & $\mathrm{c}$ & $\mathrm{a}$ & $\mathrm{b}$ & $\mathrm{c}$ & $\mathrm{a}$ & $\mathrm{b}$ & $\mathrm{c}$ \\
\hline Notch & $\begin{array}{l}\text { Body } \\
\text { Sleeve }\end{array}$ & $\begin{array}{l}18 \times 2 \mathrm{ndl} \\
\text { narrowing } \\
12 \times 2 \mathrm{ndl} \\
\text { narrowing }\end{array}$ & $\begin{array}{l}2 \text { courses } \\
4.5 \\
\text { courses }\end{array}$ & $\begin{array}{l}4.7 \\
7.0 \\
\end{array}$ & $\begin{array}{l}7.0 \\
4.7 \\
\end{array}$ & $\begin{array}{l}8.4 \\
8.4 \\
\end{array}$ & $\begin{array}{l}6.0 \\
7.5 \\
\end{array}$ & $\begin{array}{l}6.0 \\
4.5 \\
\end{array}$ & $\begin{array}{l}7.5 \\
9.0 \\
\end{array}$ & $\begin{array}{l}4.7 \\
7.0 \\
\end{array}$ & $\begin{array}{l}6.5 \\
4.7 \\
\end{array}$ & 7.0 & $\begin{array}{l}100 \\
100 \\
\end{array}$ & $\begin{array}{r}93 \\
100 \\
\end{array}$ & 83 \\
\hline Notch & $\begin{array}{l}\text { Body } \\
\text { Sleeve }\end{array}$ & $\begin{array}{l}18 \times 2 \text { ndl } \\
\text { narrowing } \\
18 \times 2 \text { ndl } \\
\text { narrowing }\end{array}$ & $\begin{array}{l}3 \text { courses } \\
2.94 \\
\text { courses }\end{array}$ & $\begin{array}{l}7.1 \\
7.0\end{array}$ & $\begin{array}{l}7.0 \\
7.1\end{array}$ & $\begin{array}{l}9.9 \\
9.9\end{array}$ & $\begin{array}{l}6.0 \\
7.5\end{array}$ & $\begin{array}{l}7.0 \\
8.0\end{array}$ & $\begin{array}{r}9.0 \\
10.0\end{array}$ & $\begin{array}{l}6.0 \\
7.0\end{array}$ & $\begin{array}{l}6.5 \\
6.0\end{array}$ & 8.8 & $\begin{array}{r}85 \\
100\end{array}$ & 93 & 89 \\
\hline Notch & $\begin{array}{l}\text { Body } \\
\text { Sleeve }\end{array}$ & $\begin{array}{l}18 \times 2 \text { ndl } \\
\text { narrowing } \\
24 \times 2 \text { ndl } \\
\text { narrowing }\end{array}$ & $\begin{array}{l}4 \text { courses } \\
2.17 \\
\text { courses }\end{array}$ & $\begin{array}{l}9.4 \\
7.0\end{array}$ & $\begin{array}{l}7.0 \\
9.0\end{array}$ & $\begin{array}{l}11.7 \\
11.7 \\
\end{array}$ & $\begin{array}{r}11.0 \\
9.0\end{array}$ & $\begin{array}{r}8.0 \\
10.5 \\
\end{array}$ & $\begin{array}{l}13.0 \\
16.0\end{array}$ & $\begin{array}{l}9.0 \\
6.5 \\
\end{array}$ & $\begin{array}{l}6.5 \\
8.5 \\
\end{array}$ & 10.5 & $\begin{array}{l}96 \\
93\end{array}$ & 93 & 90 \\
\hline Raglan & $\begin{array}{l}\text { Body } \\
\text { Sleeve } \\
\end{array}$ & $\begin{array}{l}18 \times 2 \text { ndl } \\
\text { narrowing } \\
12 \times 2 \text { ndl } \\
\text { narrowing }\end{array}$ & 2 courses & $\begin{array}{l}4.7 \\
4.7 \\
\end{array}$ & 4.7 & $\begin{array}{l}8.4 \\
6.6 \\
\end{array}$ & $\begin{array}{l}6.0 \\
5.0 \\
\end{array}$ & 6.0 & 6.5 & 5.0 & $\begin{array}{l}6.5 \\
4.0 \\
\end{array}$ & 6.0 & 106 & 93 & 71 \\
\hline Raglan & $\begin{array}{l}\text { Body } \\
\text { Sleeve }\end{array}$ & $\begin{array}{l}18 \times 2 \text { ndl } \\
\text { narrowing } \\
18 \times 2 \text { ndl } \\
\text { narrowing }\end{array}$ & 3 courses & $\begin{array}{l}7.1 \\
7.1\end{array}$ & $\begin{array}{l}7.0 \\
7.1\end{array}$ & $\begin{array}{r}9.9 \\
10.0\end{array}$ & $\begin{array}{l}6.0 \\
7.5\end{array}$ & 8.0 & $\begin{array}{r}9.0 \\
9.0\end{array}$ & $\begin{array}{l}6.0 \\
7.0\end{array}$ & 6.5 & 8.8 & 85 & 93 & 89 \\
\hline Raglan & $\begin{array}{l}\text { Body } \\
\text { Sleeve }\end{array}$ & $\begin{array}{l}18 \times 2 \text { ndl } \\
\text { narrowing } \\
24 \times 2 \text { ndl } \\
\text { narrowing }\end{array}$ & $\begin{array}{l}4 \text { courses } \\
3 \text { courses }\end{array}$ & 9.0 & 7.0 & $\begin{array}{l}11.7 \\
12.7\end{array}$ & 11.0 & 11.0 & 13.0 & 9.0 & 6.5 & 11.5 & 100 & $\begin{array}{r}93 \\
100 \\
\end{array}$ & 98 \\
\hline
\end{tabular}

(Where the fashioning frequency is a fractional number alternate frequencies have been used -2.5 courses would equate to 2 courses, 3 courses alternating)

Table 3 - Using two different empirical methods to calculate knitted armhole shapes 


\begin{tabular}{|c|c|c|c|c|c|c|c|c|c|c|c|c|c|c|c|}
\hline \multirow[t]{2}{*}{$\begin{array}{l}\text { Calculation } \\
\text { method }\end{array}$} & \multirow[t]{2}{*}{$\begin{array}{c}\text { Garment } \\
\text { component }\end{array}$} & \multirow[t]{2}{*}{$\begin{array}{l}\text { Number of } \\
\text { fashionings }\end{array}$} & \multirow[t]{2}{*}{$\begin{array}{l}\text { Fashioning } \\
\text { frequency }\end{array}$} & \multicolumn{3}{|c|}{$\begin{array}{c}\text { Theoretical } \\
\text { dimensions } \\
(\mathrm{cm})\end{array}$} & \multicolumn{3}{|c|}{$\begin{array}{l}\text { Off machine } \\
\text { dimensions } \\
(\mathrm{cm})\end{array}$} & \multicolumn{3}{|c|}{$\begin{array}{l}\text { Physical knitted } \\
\text { dimensions } \\
\text { (state of } \\
\text { consolidation) } \\
\text { (cm) }\end{array}$} & \multicolumn{3}{|c|}{$\begin{array}{c}\% \text { difference } \\
\text { theoretical and } \\
\text { physical }\end{array}$} \\
\hline & & & & $\mathrm{a}$ & $\mathrm{b}$ & c & $\mathrm{a}$ & $\mathrm{b}$ & $\mathrm{c}$ & $\mathrm{a}$ & $\mathrm{b}$ & $\mathrm{c}$ & $\mathrm{a}$ & $\mathrm{b}$ & $\mathrm{c}$ \\
\hline Raglan & $\begin{array}{l}\text { Body } \\
\text { Sleeve }\end{array}$ & $\begin{array}{l}18 \times 2 \text { ndl } \\
\text { narrowing } \\
36 \times 2 \text { ndl } \\
\text { narrowing }\end{array}$ & $\begin{array}{l}6 \text { courses } \\
2.9 \\
\text { courses }\end{array}$ & $\begin{array}{l}14.6 \\
14.6\end{array}$ & $\begin{array}{r}7.0 \\
14.6\end{array}$ & $\begin{array}{l}16.2 \\
20.6\end{array}$ & $\begin{array}{l}16.5 \\
16.0\end{array}$ & $\begin{array}{r}8.7 \\
15.0\end{array}$ & $\begin{array}{l}18.5 \\
21.0\end{array}$ & $\begin{array}{l}14.0 \\
16.0\end{array}$ & $\begin{array}{r}6.5 \\
12.5\end{array}$ & 15 & $\begin{array}{r}96 \\
110\end{array}$ & $\begin{array}{l}93 \\
86\end{array}$ & 93 \\
\hline Raglan & $\begin{array}{l}\text { Body } \\
\text { Sleeve } \\
\end{array}$ & $\begin{array}{l}18 \times 2 \text { ndl } \\
\text { narrowing } \\
48 \times 2 \text { ndl } \\
\text { narrowing }\end{array}$ & $\begin{array}{l}8 \text { courses } \\
2.85 \\
\text { courses }\end{array}$ & $\begin{array}{r}19.1 \\
19.1 \\
\end{array}$ & $\begin{array}{r}7.0 \\
19.1 \\
\end{array}$ & $\begin{array}{l}20.3 \\
27.0 \\
\end{array}$ & $\begin{array}{l}21.2 \\
20.0 \\
\end{array}$ & $\begin{array}{r}8.7 \\
19.7 \\
\end{array}$ & $\begin{array}{l}23.5 \\
28.0 \\
\end{array}$ & $\begin{array}{l}20.0 \\
20.0 \\
\end{array}$ & $\begin{array}{r}6.0 \\
15.5 \\
\end{array}$ & 22 & $\begin{array}{l}105 \\
105 \\
\end{array}$ & $\begin{array}{l}86 \\
81 \\
\end{array}$ & 108 \\
\hline $\begin{array}{c}10 \% \\
\text { Reduction }\end{array}$ & $\begin{array}{l}\text { Body } \\
\text { Sleeve }\end{array}$ & $\begin{array}{l}18 \times 2 \text { ndl } \\
\text { narrowing } \\
36 \times 2 \text { ndl } \\
\text { narrowing }\end{array}$ & $\begin{array}{l}6 \text { courses } \\
2.6 \\
\text { courses }\end{array}$ & $\begin{array}{l}14.6 \\
13.1\end{array}$ & $\begin{array}{r}7.0 \\
14.6 \\
\end{array}$ & $\begin{array}{l}16.2 \\
19.2 \\
\end{array}$ & $\begin{array}{l}16.5 \\
15.0\end{array}$ & $\begin{array}{r}8.7 \\
15.0 \\
\end{array}$ & $\begin{array}{l}18.5 \\
19.0\end{array}$ & $\begin{array}{l}13.5 \\
13.0\end{array}$ & $\begin{array}{r}7.0 \\
12.5\end{array}$ & 16 & $\begin{array}{l}92 \\
99 \\
\end{array}$ & $\begin{array}{r}100 \\
86\end{array}$ & 99 \\
\hline $\begin{array}{c}10 \% \\
\text { Reduction }\end{array}$ & $\begin{array}{l}\text { Body } \\
\text { Sleeve }\end{array}$ & $\begin{array}{l}18 \times 2 \text { ndl } \\
\text { narrowing } \\
48 \times 2 \text { ndl } \\
\text { narrowing }\end{array}$ & $\begin{array}{l}8 \text { courses } \\
2.5 \\
\text { courses } \\
\end{array}$ & $\begin{array}{l}19.1 \\
17.1 \\
\end{array}$ & $\begin{array}{r}7.0 \\
19.1 \\
\end{array}$ & $\begin{array}{l}20.3 \\
25.6 \\
\end{array}$ & $\begin{array}{l}21.2 \\
19.0 \\
\end{array}$ & $\begin{array}{r}8.7 \\
19.7 \\
\end{array}$ & $\begin{array}{l}23.5 \\
27.0 \\
\end{array}$ & $\begin{array}{l}20.0 \\
17.5 \\
\end{array}$ & $\begin{array}{r}7.0 \\
16.0 \\
\end{array}$ & 22 & $\begin{array}{l}105 \\
102 \\
\end{array}$ & $\begin{array}{r}100 \\
84 \\
\end{array}$ & 106 \\
\hline
\end{tabular}

Table 4 - Using two different empirical methods to calculate knitted armhole shapes 


\begin{tabular}{|l|r|r|r|}
\hline Dimension & $\begin{array}{c}\text { Theoretical } \\
(\mathrm{cm})\end{array}$ & \multicolumn{1}{|c|}{$\begin{array}{c}\text { Physical } \\
\text { knitted } \\
(\mathrm{cm})\end{array}$} & $\begin{array}{c}\text { \% } \\
\text { difference }\end{array}$ \\
\hline Length & 43 & 42 & 97.7 \\
\hline Chest & 46 & 44 & 95.7 \\
\hline Shoulder & 34.5 & 32 & 92.8 \\
\hline Armhole & 21 & 21 & 100.0 \\
\hline Underarm & 46 & 46 & 100.0 \\
\hline $\begin{array}{l}\text { Sleeve } \\
\text { widest }\end{array}$ & 14.5 & 14 & 96.6 \\
\hline cuff & 6 & 6 & 100.0 \\
\hline
\end{tabular}

Table 5 - Inset sleeve - body and sleeve dimensions 


\author{
List of Figures \\ Diagram 1 - Traditionally cut armhole shape $V$ fully-fashioned armhole. \\ Diagram 2 - Armhole geometry \\ Diagram 3 - Pythagoras Theorem \\ Diagram 4 - Garment component alignment \\ Diagram 5 - Inset sleeve panel alignment
}



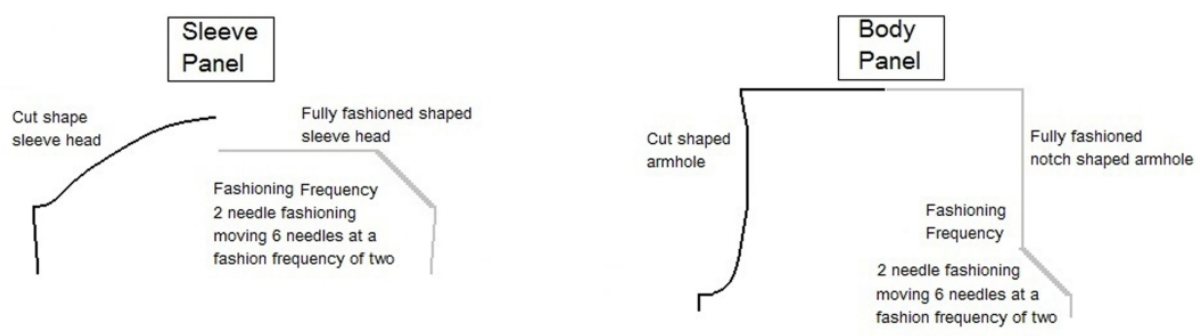

Diagram 1 - Traditionally cut armhole shape $V$ fully-fashioned armhole $135 \times 34 \mathrm{~mm}(600 \times 600 \mathrm{DPI})$ 
1

2

3

4

5

6

7

8

9

10

11

12

13

14

15

16

17

18

19

20

21

22

23

24

25

26

27

28

29

30

31

32

33

34

35

36

37

38

39

40

41

42

43

44

45

46

47

48

49

50

51

52

53

54

55

56

57

58

59

60

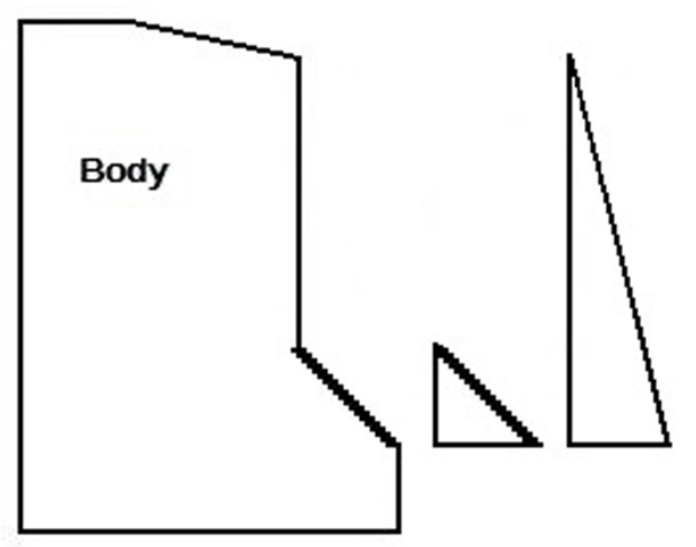

Diagram 2 - Armhole Geometry

$131 \times 69 \mathrm{~mm}(600 \times 600 \mathrm{DPI})$ 


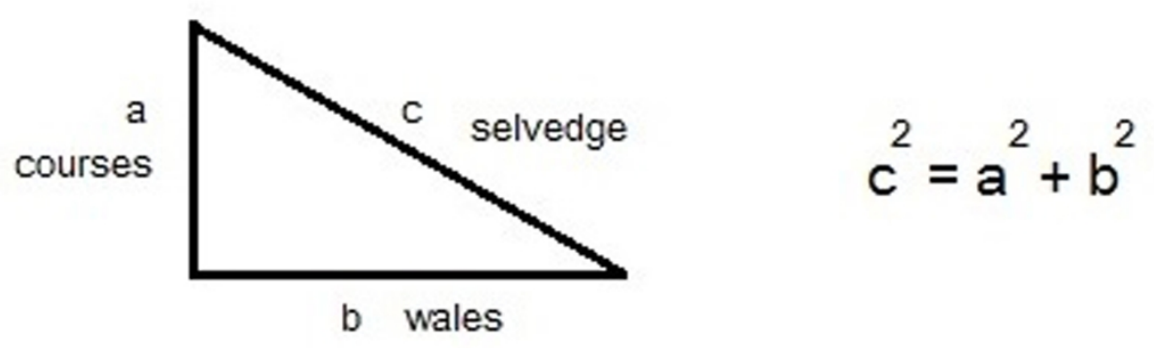

Diagram 3 - Pythagoras Theorem

$113 \times 34 \mathrm{~mm}(600 \times 600 \mathrm{DPI})$ 

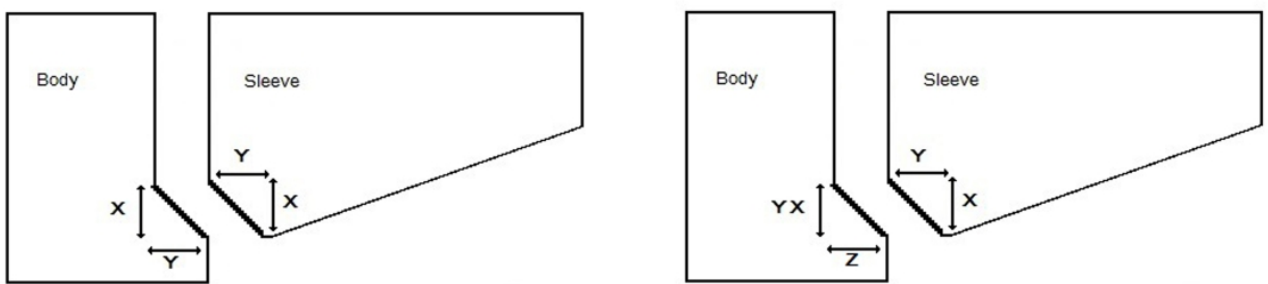

\section{Diagram 4 - Garment component alignment $247 \times 69 \mathrm{~mm}(600 \times 600 \mathrm{DPI})$}




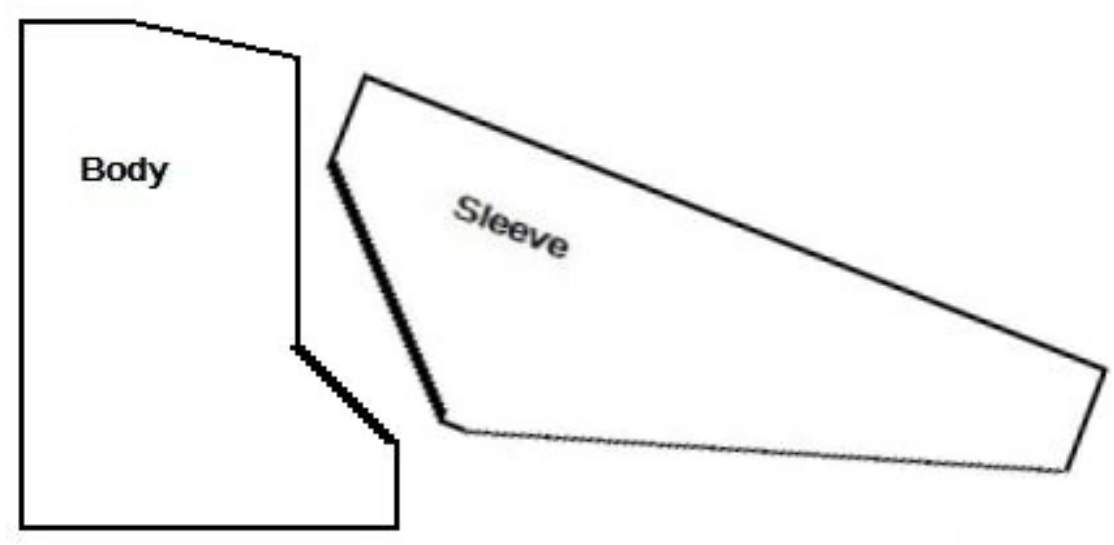

Diagram 5 - Inset sleeve panel alignment

$131 \times 69 \mathrm{~mm}(96 \times 96 \mathrm{DPI})$ 